\title{
RESTORING JUSTICE AND AUTONOMY IN SÁMI REINDEER HUSBANDRY
}

JAN ERIK HENRIKSEN AND IDA HYDLE

\section{ABSTRACT}

In this chapter, we link experiences and knowledge from fieldwork conducted between 2014 and 2018, with methodological and theoretical grounding in social work, anthropology and medicine. Our interests are decolonisation, the Sámi as signposts of indigeneity and ecological sustainability. Our research questions the present and future policies in Sámi areas, by investigating decolonising initiatives and measures, and by taking conflicts within reindeer husbandry to be a signpost. We question whether conflicts and confrontations in reindeer husbandry exemplify neo-colonisation and therefore the need for alternatives to present state policies and practices. One alternative that we suggest is the implementation of restorative justice in reindeer husbandry conflicts. Restorative practices (embedded in local indigenous knowledge) may act as an important decolonising tool.

Conflicts and their aftermath arose in Norwegian reindeer herding with assimilation (Norwegianisation), the loss of pasture through forced migration and the implementation of national regulations that arose from the state settling regime. These ruptured Sámi traditions and rituals, not least reindeer husbandry and herding from the $18^{\text {th }}$ century. We therefore investigate, in our work, a view of indigeneity that extends the modern, administrative definition 
by not only including, but intersecting, social with ecological sustainability. Norwegian Sámi reindeer policy is currently conducted as self-government, based on the state's explicit New Public Management (NPM) polity. Our aim is to investigate the rise in conflicts between the Norwegian authorities and Sámi, and within the Sámi siidas (reindeer herding collectives) at both a structural and local level, to argue that the explicit NPM focus on fixed limits and maximum numbers leads to an increase in conflicts. Reindeer husbandry management should, instead, take traditional knowledge into account. As one reindeer owner said to us: "One year is not the previous year's namesake or brother. A living nature requires flexibility and adaption".

\section{INTRODUCTION}

Reindeer herding and its multiple traditions (such as the knowledge of handling animals, land, climate, and grazing) are generally acknowledged to be a primary historical basis for Sámi languages, culture, traditions, cosmology and communication. The herding of reindeer is also of key importance to survival and income. It is a way of life, reindeer until recently being a crucial source of meat, of hides for clothing, of antlers and bone for tools and jewellery and for transport (Riseth \& Lie, 2016; Sara, 1992; Sara, 2013)

Reindeer herding is considered to be the primary reason for Sámi language survival in Norway during 'Norwegianisation', which took place from 1850 onwards. It also played a decisive role in the formation of what became Finnmark and the existence of this county's population. We consider that the governance of Finnmark County has played a significant role in the development of the conditions for reindeer herding development. This also true in the other five Norwegian counties and parts of Northern Sweden where there is Sámi reindeer herding. We therefore claim that our research is applicable to other reindeer herding landscapes. According to The International Centre for Reindeer Husbandry (ICR), established by the Norwegian Government in 2005 in Guovdageaidnu/Kautokeino (Finnmark), there are '24 different Indigenous Peoples which base their lives on herding domesticated reindeer today. These nomadic reindeer herders live across the entire circumpolar Arctic and Sub-Arctic region, including areas in Sweden, Finland, Norway, Russia, China, Mongolia, US/Alaska, Canada, Greenland and Scotland. These groups 
currently herd around 2.5 million domesticated reindeer, and are altogether close to 100000 people, all included'.

These man-animal traditions and herding relationships represent a considerable proportion of global Indigenous Peoples' knowledge and traditions. Veterinaries, climatologists, ecologists and biologists now, furthermore, see reindeer as an indicator of global climate change and the Arctic as the most vulnerable area to $\mathrm{CO} 2$ emission and to the consequences of temperature increase (Cassella, 2019).

Conflicts between private and state-based enterprises and reindeer husbandry have increased after the Second World War. This is due to the growth in industries such as hydroelectricity, wind power, mining, oil and gas, national and NATO military geopolitical strategic use of territories and tourism. Many of the most major conflicts between nature conservationists/Sámi and the Norwegian authorities after World War 2 relate to the traditional lands that are important to herds and herders. A significant example was the construction of the Alta - Kautokeino dam in the 1980's. Reindeer and salmon are key resources (and animals) for the Sámi. The reindeer is also an important figure, as in Santa Claus' reindeer Rudolf. The reindeer, however, is also an important carrier of Sámi traditions, culture, language, identity and income. State requirements that only view reindeer herding as an economic resource are seen to be counterproductive.

The case we describe below is therefore one that is of crucial importance. A recent lawsuit was brought by the Norwegian government concerning the size of reindeer herds. The defendant, a young Sámi reindeer herder (owner), however won the case at two court levels. The state appealed the case to the Norwegian Supreme Court, and won. The reindeer herder appealed the case to the European Court of Human Rights, supported by The Norwegian Sámi Parliament, which also demanded a revision of the Reindeer Husbandry Act. The Ministry of Agriculture and Food did not take into consideration that these appeals were in progress, and demanded the herd be reduced to 75 animals. This is not a size that is economically viable for a family. The argument presented by the Ministry of Agriculture and Food was that the conflict should be handled internally in the siida (reindeer pastoralistic district). This case and the cases we describe later in this chapter, point to two crucial problems. One is the question of territorial borders and maximum herd numbers. The other is the clash between two governing principles, NPM and traditional, flexible Sámi reindeer herding (Larsen \& Røyrvik, 2017). 
Norwegian legal scholars, local and national politicians, and the Norwegian reindeer herding organisation (NRL) are currently discussing the reasons why the Norwegian government regulation of Sámi reindeer herding has gone so wrong, and why there are conflicts over land and grazing areas. The traditional ways of organizing herding and the semi-nomadism this requires, has almost been destroyed and the ecological and economic basis of herding equilibrium has also been severely damaged. The consequences of this impacts the people, animals and grazing areas of six of Norway's 19 counties. It also impacts a wide area that includes the Arctic areas of Sweden, Finland and Russia. The failure of these four Arctic state's attempts to achieve 'modern regulation' is widely known and accepted by both central and local authorities. Attempts to restore or improve conditions in the last decade have, however been unsuccessful. The poor conditions therefore continue.

Countless research documents produced by lawyers and social scientists across Sápmi, (the indigenous Sámi populations of Russia, Finland, Sweden and Norway) in the last three centuries disclose how state governance has not been built on Sámi herding expertise and legal and traditional use of and rights to the land. It is instead based on racism and illegal confiscation of civil rights lands, rivers and fjords (see e.g. Bjørklund, 2004; Bjørklund \& Marin, 2015; Dahlstrøn Nilsson, 2003; Elenius, Allard, \& Sandstrøm, 2016; Hydle \& Henriksen, 2016; Ingold, 1996; Riseth, Tømmervik, \& Bjerke, 2016; Riseth \& Lie, 2016). State policy seems to aim to promote the growth of Sámi autonomy as signified by, for example, the Sámi Parliament and the Finnmark Act. Double-bind governance however seems to exist, NPM policy colliding with the traditional procedural and flexible reindeer Sámi way of thinking. Reindeer Sámi applications for support to cope with these contradictions are also rejected by the state, the state arguing that such dilemmas are not part of public legal solutions. The state stipulates that this should be resolved by the reindeer Sámi themselves, and through the involvement of lawyers. We question whether double-bind governance has, over time, expanded the conflicts in reindeer husbandry?

Our fieldwork and this chapter describe what happened when we suggested restorative justice as a way of handling these conflicts. This approach informs and links the conflicting parties through an experiment at the Norwegian Mediation Service. Restorative justice is a theory and practice of conflict resolution within the civil and public societal sectors. Its aim is to involve those 
involved in the conflict, in democratic processes and to through this achieve a peaceful resolution. Our research in this field started with the question: Can the application of restorative justice contribute to the better handling of conflicts in Sámi reindeer herding?

There is a growing need to find sustainable solutions. This includes within the handling of the new public management of the state, which privatises conflicts that are part of past and present state governance. These conflicts are therefore privatised into so-called private civil legal cases, which are handled by the courts. This 'solution' is often extremely costly to Sámi reindeer owners, their families and local communities. State governance furthermore becomes, through treating each as an individual case or lawsuit, invisible and free of all responsibility. Our data also shows that court decisions only occasionally solve these conflicts at the person or community level.

\section{METHODOLOGICAL AND THEORETICAL PERSPECTIVES}

We are two scholars whose professional and personal backgrounds, experience and positions inherently comprise a wide range of representations. This is of importance to the research described in this chapter. A short excerpt of our biographies is therefore an inescapable part of the empirical basis of the ontology and epistemology of this presentation, as underscored by the American anthropologist Renato Rosaldo for example (Rosaldo, 2017). We are both professors of the same university department, in the same fields of restorative justice, indigenous studies and marginalisation. We, however, have built a bridge between what separates us - ethnicity, cultural heritage, geographical home, age and gender. The aim of restorative justice is to create a relationship and a dialogical process between stakeholders and the local community that is both acceptable, and leads to an agreement between the parties involved. This process is not per se about achieving agreement, but about achieving a resolution in peace. Stakeholders who are directly involved may play an active role in the dialogue, including presenting resolution proposals. Conflict transformation can be achieved quickly and directly or across a number of stages over time. This can be in the form of payment, work carried out in lieu, or in any way the parties agree. Directly involved stakeholders (victim and offender), the indirectly involved (family, friends or others), and 
primary stakeholder support persons are all seen as being (perhaps secondary) stakeholders of the conflict, and thus also of the solution (Hydle, 2013; Hydle, Foss, \& Lønneberg, 2014; Zehr, 2014).

We follow anthropologist Phillip G. Gulliver's approach to dispute management: 'Negotiations do not occur in a socio-political vacuum. They are intricately enmeshed in ongoing, wider social processes that constitute their essential environment and to which negotiations themselves contribute and often modify' (Gulliver, 1979; 1988, p.249). The negotiation cases presented here must, therefore, be understood as being extended social processes, and not separate entities.

Our ongoing and common research planning, participant observations and analysis in the multi-sited fields of Sápmi and the nation states' context, are results of this particular mixture of personal, professional and disciplinary breadth. We, together, therefore not only encompass these research areas, but also the Sámi language, practical reindeer herding experience, ecology and sustainable knowledge. As academics and socially engaged professionals, we also share knowledge about the political and structural conditions of our society. We are both keen to convey the experiences that take place between the system of governance and the reindeer-based world of living. As 'wordwarriors' (Turner, 2006), we are both concerned with knowledge that might contribute to conflict resolution and change.

The interlocutors of our fields of interest include: 1) Sámi reindeer herders, 2) representatives of the reindeer herding organisation, 3) Norwegian state representatives of the Ministry of Agriculture in Oslo and Finnmark, 4) members of the Sámi Parliament (the special legal authorities for the governance of Finnmark county), 5) representatives of the local Norwegian Mediation Service and secretariat coordinators in the Ministry of Justice in Oslo. We also include in our study public documents, laws, court decisions relating to reindeer herding conflicts, and debates in local and national newspapers. The difference between interlocutors' facilities and resources are huge. Sterile glass and concrete offices in high rise buildings surrounded by heavy traffic, knowing hardly anything about reindeer or Sámi culture as opposed to the Arctic tundra in minus 30 degrees $\mathrm{C}$, on a snowmobile with a herding dog on the back seat, surrounded by reindeer looking for food. We have, with Judge Knut Petterson who is a specialist in Sámi court cases, analysed 29 court cases 
that relate to reindeer herding conflicts. This forms the backdrop for the four cases, which contain generalisable experiences.

The mixture of our origins led us to the construction of a particular network and to multiple site Nordic reindeer herding fieldwork. The anthropologists Biehl and Petryna (2013) describe the crucial role of ethnography in global health research, and argue for a comprehensive, people-centred approach. Our way into this field was through meeting people in their field, with or without reindeer around them. Reindeer, if not literally present, were 'there' on screens, pictures on walls or as food being offered and shared. We followed Biehl and Petrynas' and Geertz's 'thinking-in-cases'. There is a shortage of both anthropological and social scientific studies of present-day reindeer herding. Using ethnographic case studies as an approach to the field should therefore make an important contribution. We identify the policies that supposedly 'work' or, as we show, do not 'work', through the analysis of our data and to a certain extent evaluation. Our explanatory model should be able to replicate or scale up 'across a range of often widely divergent social contexts and geographic locations' (Biehl \& Petryna, 2013, p.12). Following this, we share Biehl and Petrynas' thoughts on ethnographic case studies, which 'brings granular ethnographic evidence to the forefront of analysis and enables analogic thinking'. We use their advice to pay 'close attention to particular realities on the ground and to the metrics in which they are cast' (Biehl \& Petryna, 2013, p.13) to highlight the productive and uneasy coexistence between the Nordic neoliberal systems' design of reindeer herding polity and the alternative models crafted by the people for 'engaging the real... worlding world" (Cadena, 2015).

This approach coincides with and works well within Indigenous Methodology, and is applied to marginalised research areas that are often excluded from mainstream research issues. The aim of this approach is, for example, to change perspectives, turn viewpoints into new positions, and challenge academic thinking and expressions (Drugge, 2016). 


\section{DATA PRESENTATIONS, CASES FROM OUR FIELDWORK}

\section{FIRST CASE: CARTOGRAPHY}

A number of scholars at a meeting at the Sámi University College in Guovdageaidnu/Kautokeino mentioned the problem of cartography:

'There are many examples of this, meetings where the authorities have taken control of the local siida management, demanding siida owners 'draw the border of your siida!'. Many lines here or there, without sense. The authorities behave as if they have no knowledge. The reindeer herders also get the impression that they themselves have no knowledge of their own. ... There must be borders. But those borders are not drawn on a piece of paper. They are verbally justified. An example is that 'this coombe has always functioned as a fence'. Traditionally people did not use maps. This is a new medium that contributes to an increase in the level of misunderstandings and conflicts... A map only functions if reindeer movement reflects this. If not, a map is of little use, because there is a big disparity between reality and a map', to quote several of the discussants at the meeting.

We have observed, throughout our fieldwork, the overall and consistent use of maps as a method in the authorities' governance of reindeer herding. They use maps because it is an easy, straightforward and neutral way of following up their rules and regulations. Reindeer owners and herders do not, however, recognize themselves in the authorities' maps and descriptions of the terrain. The understanding of owners and herders is based upon the migration of the reindeer, climate, snow, ice, wind, rivers, creeks and lakes, which vary from year to year, season to season. The authorities have four seasons. Reindeer herders have eight. This is impossible to draw on a two-dimensional piece of paper.

Maps can be used to conquer. They can be used to govern peoples' opinions, actions and understandings of a terrain, a landscape and a policy. They have also been used to govern and administer colonised land in all European acquisitions of former and to some extent remaining colonies. Cartography is the science of mapping, a western scientific way of reading a terrain. A 
terrain may, however, be read in at least three different ways. A map can be a cognitive system, which differs from culture to culture (Ben-Ze'ev, 2012). We gradually saw, in our work, how two different systems for understanding the terrain were incongruent. A map can furthermore be an expression of material culture. We saw this when the authorities named a mountain or a particular space which the Sámi held as holy, due to religious, historical experiences or burial sites. A map is also a social construction. It is socially created. Someone has agreed upon the interpretation of drawings, lines, colours and how to read them (Hunt \& Stevenson, 2016; Woodward \& Lewis, 1998).

\section{SECOND CASE: CROSS-BORDER REINDEER HERDING}

Nomadic reindeer herding has become more and more trapped by state borders as the Norwegian, Swedish, Finish and Russian lands have been gradually nationalised into nation-states. This was particularly true in the 1800 s. It is, however, still today the cause of considerable problems to man, animal and state authorities. The shifting and closing of borders between the Fennoscandian nation states followed as result of several wars. Sámi reindeer herding, which was traditionally defined by grazing land within Sápmi (Fennoscandia as a whole), was therefore gradually locked in and defined as either Norwegian, Swedish, Finish or Russian. The Skolt Sámi group was divided into two by being forced to choose to remain in Finland or Norway. Herders found themselves under surveillance by state authorities, trapped between nation states' differences in the legal acceptance of Sámi civil rights, and in states' theft of these rights on both sides of the borders. We travelled to meet Sámi reindeer owners and villagers on both sides of the Swedish-Norwegian border, whose grazing land of times immemorial were now defined as being either on the Norwegian or Swedish side of the nation state border. The old reindeer husbandry agreement between Norway and Sweden from 1751 was not extended beyond 2005. Reindeer herders could therefore no longer pasture their traditional land. We found consequences, whilst carrying out our fieldwork. Sámi reindeer owners were fined in a number of counties, for herding in areas that were now claimed by municipalities, state or private industries, farmers (that had been given the land by the state) and the armed forces to be their property. Each fine has to be responded to by the Sámi herders, through lawyers and court cases. 
"Two of my brothers have committed suicide during one of these court cases", one herder on the Swedish side said desperately:

We don't know how far this will go. The Norwegian municipality has fined us more than NOK 8 million, in spite of us winning the Norwegian supreme court case against them many years ago.

The Swedish political scientist Anette Löf similarly underscores, in her PhD study, that the governance of Swedish Sami reindeer husbandry remains mainly hierarchical and is characterized by inconsistencies. 'In contrast to well-established narratives of increased participation and indigenous peoples' right to self-determination...there are large differences in understanding between key actors and, over time, only marginal change - in governing structures and meta-images. Thus, reindeer husbandry actors appear to be locked out of essential governing functions and locked into a system that is proving hard to change' (Löf, 2016, p.426).

The Swedish head negotiator of a new reindeer herding treaty between the two states, Lars Norberg (Sámi name: Udtja-Lasse), was a skilled and respected diplomat. He had been Sweden's lead negotiator during the Balkans war. He described his negative experiences with reindeer authorities on both sides. His conclusion was that the Swedish state had been trapped and thereby given away the grazing rights for the Swedish Sámi on the Norwegian side. And in that trap the Swedish stated had fastened (Udtja-Lasse, 2007). Udtja-Lasse's book on the negotiations is symbolically part of the same title as "Bury my heart at Wounded Knee" by the native American Dee Brown (Brown, 1970). It bears the same message of state governance as neo-colonialisation of the Sámi people by Norwegian and Swedish state authorities. Udtja-Lasse thereby compares the negotiation and its background history with the American government's continuing effort to colonise culture, religion, and the way of life of Native American peoples. The Nordic case does not contain the same level of violence, murder and rape as the American. The way that the land is exploited is, however, the same. The consequences for people, animals, culture and way of life have much in common. 


\section{THIRD CASE: WHEN A FENCE TURNS FRIENDS INTOENEMIES}

One of the cases we studied relates to an area that is used for summer grazing by one siida and for moving a reindeer herd by the neighbouring siidas. We studied this case using text analysis, interviews and by being in court. The two neighbouring siidas were friends, and had a joint secretary 15 years ago. The authorities had, however, interfered in the Sámi traditional land use at least twice, causing pressure and conflicts on other neighbouring areas. Some of the siidas managed this through cooperation. Others built fences to keep out the neighbouring siida. In this case, siida $A$ set up a long illegal fence. Siida B protested and claimed that the fence prevented their traditional moving pattern. Siida A was forced by the reindeer authorities to remove the fence. Both siidas engaged lawyers and expert historians and brought the conflict to the courts. Siida B won the case. Siida A, however, appealed and won in the court of appeals. The siida who lost the case is now claiming a miscarriage of justice. They are now bitter enemies after having been close friends for at least three generations. Both parties have also spent millions of krone on lawyers and expert witnesses. All those who know a little about this case say there are no winners, that the case should never have been brought to court, and that it could have been solved by mediation. The Norwegian mediation system, however, lacks Sámi knowledge and the reindeer authorities have not prioritised the development of the promised reindeer mediation system.

Our data shows that court decisions do not solve conflicts. One of the representatives of the county reindeer herding authorities explained how the case was dead now. At the same time, he had not heard that they (the litigants in court) had a reasonable dialogue. This often ended up with people not talking to each other, and sending sarcastic e-mails.

We met with positive and knowledgeable people from both siidas. A number of people in the community also said that they did not agree with the court decision. Some were angry and would never agree to reconciliation. They also claimed that the Norwegian state was responsible for the overall scenario of such civil law suits and cases between the siidas. Its governance of Sámi reindeer herding brings siidas into impossible deadlocks. The state and its authorities, however, make themselves invisible in this through direct or indirect governance. The local authorities have, furthermore, no means to adapt, intervene or give a helping hand. Some told us of their helplessness and sadness at being in such a squeezed position. 


\section{FORCED REDUCTION OF REINDEER HERDS: THE JOVSSET ÁNTE SARA CASE.}

The state's lawsuit against the young herder Jovsset Ánte Sara has received international media attention. Sara refused to comply with the demands of the state authorities to reduce his reindeer herd from 116 to 75 . This demand was articulated as being a part of the authorities' long-term struggle to reduce the numbers of reindeer, due the much-discussed introduction of reindeer numbers per acre of grazing area and calf weight combined with an NPM model, the state setting a fixed maximum number of reindeer for each district. In the 2007, the Reindeer Husbandry Act introduced a clause that stated that if all reindeer owners in a district did not agree to reductions, then the government would stipulate an equal percentage reduction for all siida shareholders. Sara won his case both in the District Court and in the Court of Appeal. The District court claimed that the state's demand for a reduction violated property protection according to The European Convention on Human Rights P 1-1. The Court of Appeal rejected the state's appeal, based on the UN International Covenant on Civil and Political Rights, article 27. The state's decision on reindeer herd reductions meant that the reindeer owner no longer could achieve economic surplus. There is a threshold which defines whether an intervention can be seen as being legitimate, even though the Reindeer Herding Act's provision on reindeer numbers and reductions is based on what the Norwegian state regards as reasonable and objective grounds. This also relates to the state's reindeer herding governance. The threshold for illegal intervention was exceeded in this case. The state appealed the case to the Supreme Court, which upheld the state's claim on reduction. The Sámi Parliament supported Sara, who appealed the case to the United Nations Human Rights Committee in Geneva, and which is still in progress (Dec. 2019). The Ministerial authorities threatened the forced slaughtering of Sara's reindeer. The case resulted in demonstrations in front of Parliament and considerable support from many different population groups, particularly artists. The arguments from the state (the Ministry of Agriculture and Food) were based upon arguable assumptions relating to ecologically, economic and cultural sustainability and animal welfare. These arguments were, however, rebuffed by professors in the environmental sciences as a policy that was arrogant, lacking in knowledge and that bore no relation to the facts. 
The resistance and demonstrations forced the authorities to await further decisions. Just before Christmas 2019, Sara's sister told us that a solution to the conflict seemed to have been achieved. This arose not out of the authorities' willingness to resolve the issue, but through dialogue with another siida. Jovsset Ánte Sara has re-branded his reindeer and transferred them to his mother's siida. A reindeer herder in this siida had ceased reindeer herding and there was now sufficient quota to incorporate Sara's reindeer and him as the herder into this siida.

We experience, in this case, that the Ministry of Agriculture and Food reproduces the 'Norwegianisation' of Sámi reindeer herding and furthermore prolongs the 'Norwegianisation' of the Sami people, its language and culture. The District Court and the Court of Appeal upheld Sara's claim that he cannot exist and exercise his human rights with only 75 reindeer. The Supreme Court used other premises in arriving at its decision. Sara has a collective right to exercise his culture. This is the guiding principle. The state, at the same time, sees itself as the defender of sustainability principles. It is therefore a fundamental paradox that reindeer herding has been given administrative rights, but within principles that are so narrow that this right cannot be exercised.

\section{NPM VERSUS A TRADITIONAL REINDEER HERDING PERSPECTIVE}

Cartography is an example of the state's neoliberal governance, and is a tool which reindeer owners can use to map borders of reindeer tracking as a part of a governmental agricultural and homogenising policy. It is, however, not a useful tool for Sámi reindeer herding. All four cases clearly illustrate the crucial problem of fixed borders on a map materialising as high fences in the terrain and a fixed maximum number of reindeer in each siida. As one of the reindeer owners said: "Next year is never the namesake or brother of the recent year", in the sense that natural, climate variations demand variability and flexibility in herd numbers and borders. All the cases therefore reveal the fundamental categorical mistake in the state's governance.

Does restorative justice have a role to play in reindeer herding conflicts in Fennoscandia? If we keep to the term neo-colonialism, then most of our state representative informants do their very best (and as a part of a civilizing mission) to educate, convert, and assimilate the other, i.e. to include Sámi and 
their reindeer herding traditions into the empire of the state and the NPM of agricultural governance. This acts as an indirect part of the 'Norwegianisation' of the Sámi. They, in other words, try to convince the Sámi that they will benefit form being a standard Norwegian 'farmer' and 'one of "us", if they accept the conditions that relate to bordering, herding, grazing, slaughtering and marketing. The mechanisms of this type of neo-colonialism today seems to include state subsidies, taxation rules, changing legal provisions and regulations. They are therefore not attuned to practical reality, distribution of part-governance locally and nationally, to Sámi institutions such as the Sámi parliament (without parliamentary power), the Norwegian reindeer herding association, and to the reindeer herding districts and siidas (the collectives). This is reminiscent of the pre-colonial time. The colonizers not only intended to dominate, but also to 'civilize' and 'save'. Civilising in this context also means 'modernised agricultural reasoning and praxis', although this reasoning and praxis has an unsurpassed power to ruin climate, soil, forests, animals and man. There are all in all therefore a number of categorical mistakes in play. Firstly, adjusting the herding of nomadic animals to a non-nomadic herding praxis. Secondly the forcing of Norwegian (or Swedish or Finish) language, social, cultural and religious traditions upon the Sámi population (up to the late 1960s). This broke the Sámi cultural ground and partly shattered and turned them to shame, to social, material and welfare decline.

One example is the Programme for Change for Inner Finnmark. The Norwegian state spent NOK 330 million in the period 1993-2000 on this program. The aim was to retrain reindeer owners out of reindeer husbandry, and to improve education, competence and welfare in reindeer husbandry. This was prompted by difficulties relating to resources, economics and the social situation within reindeer husbandry. The results were disappointing, both for the industry and their welfare (Angell, Karlstad, \& Nygaard, 2003; Bergland, 2005). Today, 2019, our experience of the conflicting parties is that they live with a great deal of insecurity and lack of clarity. There is also external pressure on grazing areas and contested ownership, both for land and reindeer. This also leads to feelings of symbolic violence, considerable stress and a number of suicides in the herding population (Kaiser \& Salander Renberg 2012; Kaiser, Sjølander, Liljegren, \& Jacobsson, 2010; Møllersen, 2018; Møllersen, EiraÅhren, Stordah1, \& Tørres, 2013; Stoor, 2016)

The rising level of internal and external conflicts can be measured in the courts. The media and non-Sámi residents describe reindeer husbandry in 
negative terms, alleging 'backwardness', harm and violence (Henriksen, 2008). Increasing the numbers of conflicts brought to court does not solve the multi-layered nature of the conflicts. The conflicts continue after court decisions have been pronounced. The conflicts are also shown to be both socially and economically disastrous for owners, families, siidas, and communities. The lawyers are the only people who benefit from the cases, through the fees they charge. This fact is much discussed and regretted by both Sámi and public authorities, and is very well known to all locals. (For a later empirical presentation: "the authorities escape the responsibility for keeping/upholding the state of law, and push us over to private civil legal solutions that cost us millions of kroner"). Even if reindeer owners and public reindeer authorities regret this development and see the detrimental effects, they still seem to accept it. We, as participant researchers have followed these processes closely in Finnmark County in recent years. Also some examples from Troms and Nordland county and from Northern Sweden, where samebyar (reindeer herding collectives) have, for example, summer grazing areas on the Norwegian side of the national state border. Cultural, social and symbolic power are hidden. Reindeer herders, at the same time, face greater hindrances, in almost impossible demands from state authorities for participation in hearings on societal changes. These claims for participation in the development of society, or what we refer to as the 'protection of this vulnerable Indigenous way of life' take almost all their time, leaving too little time for herding. The siidas have started a so-called complementary branding practice, in an attempt to fight the 'bit by bit' expropriation or destruction of grazing lands for electric power, mining, cabins or tourism. The siida now point out previous destruction every time the authorities use the term development within the pastures of the siida. Comments previously only related to the specific case, the result often being that grazing land was destroyed 'bit by bit'. Reindeer husbandry hopes that complementary branding practices can reduce the burden of destruction and create a better understanding of why they often say no to 'development'.

Responsibility for harm and suffering is left to the lowest part of the governance chain. The contexts, structures and processes leading to the harm and suffering seem, therefore to be invisibilised. The book 'Samisk Reindrift - norske myter' (Sámi reindeer herding - Norwegian myths, our translation) (Benjaminsen, Eira, \& Sara, 2015) is an attempt to deconstruct the arguments of the Norwegian authorities on 'unsustainable' Sámi reindeer herding, and its implementation through the laws and rules of a NPM regime. Many siidas 
and reindeer herders do not acknowledge this, and reject these reforms using arguments based upon tradition and experience. Our data show that they are indirectly forced into destructive conflicts and into paying for private legal advice, both in and outside of court. The Norwegian parliament approved the Reindeer Husbandry Act in 2007. The act contains an article on mediation. This is has only rarely been used, due to a lack of the statutories promised in the Act. When we ask state authority representatives why nothing has been done over the last nine years, they say that there have been so many other challenging tasks relating to the reduction of reindeer herds, processes in the market to, for example, increase the demand for reindeer meat, reorganization of the reindeer authorities and increased self-determination of reindeer husbandry. These priorities of the Norwegian agricultural authorities has clearly increased the conflict level in Sami reindeer husbandry.

We see that part of the neo-colonial and NPM system development is to expand juridical power, juridification, and the growing importance of law, legal discourse and legal institutions in Sámi and in general, such as within Norwegian welfare institutions. Sieder in her chapter 'Legal cultures in the (un) rule of law: Indigenous rights and juridification in Guatemala' uses the definition of juridification by Guillermo O'Donnell: 'the mounting degree to which social relations, formerly left to autonomous and/or informal regulation, are being textured by formal legal rules'(O'Donnel, 2005:293 in Sieder 2010:161). She develops this by stating that: 'Broadly speaking, in Western Europe and the United States, juridification signals Weberian processes of bureaucratization and the expansion of law into more and more areas of social life, such as industrial relations, social welfare provision, and economic production'(Sieder, 2010, p.161).

A number of recent ongoing law cases at all three administrative levels manifest the superiority of national legislation over Sámi traditions. This includes ecological or social judgements. There may, however, be a pitfall in oversimplifying the negative force of national law as a paradigm of power and domination. Law may not only be used as a matter of negative or suppressive social control or governmental power. Law may also have the 'capacity to provide a meaningful map or a model for the world'. Law has, to a certain extent, been shown to act as an instrument of social change, such as the Indigenous rights of the Sámi in Norway. The nationwide and partly illegal demonstrations in 1979 -82, that include serious hunger strikes, imprisonment, high fines and social and personal suffering, led to the establishment of the Sámi 
parliament. This parliament has consultation rights to the national government. It illustrates that legal structures can represent a landscape of possibilities for disadvantaged groups ${ }^{20}$. Sámi reindeer herders now see themselves as fighting against 'the system'. They, however, also use the tools provided by this very 'system' in this fight. To some extent, 'the system' also gives them tools to undermine the 'system', in this case the Norwegian NPM of reindeer herding, as shown by our data presentation. Indigenous rights, when or if implemented, may therefore be a powerful instrument of social change ${ }^{21}$. The law may, in that context, be seen as facilitating social cohesion. In other words, the cases that we present not only relate to the outcomes of legal disputes or restorative justice efforts, successful or not. Single outcomes may not be of crucial importance in the long run. Gulliver recognises that a majority of social scientists who study negotiations, search for an explanation of outcomes. Our work has been led by the ambition to find explanatory powers and to tracing as far as possible 'all the serious interactions which precedes, affects and sets up the end-game' (Gulliver, 1988, p.251). They are personal stories, experiences in Norwegian reindeer herding, Sámi policy and history, climate and areal changes. Histories of significant localities. Aspects of which are not only a background for negotiations and outcomes, but of significant players.

\section{CONCLUSION}

The most recent Norwegian Reindeer Herding Act from 2007 may be regarded as a reform that aims to regulate both man (Sámi owners) and animal (reindeer), the relationship between them and the political and social changes required to achieve these aims. Our study of such a political, social and cultural reform cannot be limited to the study of organizational changes from the perspective of just Norwegian reindeer herding act institutions and governmental bodies. It must include the individual, the subjectivity and the narrative, including the transnational pattern of Sámi reindeer herding. Through this we can bring critical insights into questions on how policies translate into the lives of the people that they aim to address.

Our aim was to approach the Sámi reindeer herders understanding of themselves as 'owners' with 'Sámi rights' and to explore how both reindeer owners and reindeer bureaucrats actively engage with the socio-political categories and labels, and use them to interpret or cope with the social and polit- 
ical culture of suspicion that we have shown to exist in the cases. We have focused on reciprocal relationships between social categories, herding behaviour and identity by looking and listening to their everyday practices and ways of dealing with traditions, laws, rules and mistrust. Our final analysis looks into the transformative powers of bureaucracy and law, in particular questioning ourselves as researchers. Given the present political situation, could our quest for the use of a restorative justice approach be transformed into a legal instrument that the state could use to continue the neo-colonisation of Sámi and Sámi reindeer herding? If the answer to this is yes, then 'restorative justice' can be turned and used to achieve the opposite of that intended. It can be converted into a tool that can disguise Sámi civil rights and their national and international citizenship.

Sámi from the Swedish, Finish and Norwegian sides, have demanded that their governments establish a truth commission for past colonisation of Sámi heritage, culture and language. The Finish and the Norwegian governments have recently established a Truth and Reconciliation Commission, which will investigate the consequences of the assimilation of the Sami as an Indigenous people and the Kven people as a national minority. Reindeer herding and husbandry is seen to have a crucial position in Sámi cultural and language traditions. We therefore believe that truth commissions must include the consequences of past and present state governance of Sámi reindeer husbandry, which our findings show have seriously damaged shared traditional knowledge and herding practices. The question however remains of the extent to which this governance is assuming new forms and is continuing to harm indigenous ecologically based practices and traditions. Our work on finding new ways to achieve justice and autonomy in reindeer husbandry conflicts, may serve as an empirical example in similar conflict fields.

\section{ACKNOWLEDGEMENT}

We would like to thank the Research Council of Norway and the Reindeer husbandry development fund for the co-financing of the project on mediation in reindeer husbandry. 


\section{LITERATURE}

Angell, E. Karlstad, S., \& Nygaard, V. (2003). Samiske samfunn i omstilling.

Sluttevaluering av Omstillingsprogrammet for Indre Finnmark.

Ben-Ze'ev, E. (2012). Mental maps and spatial perceptions: The fragmentation of

Israel-Palestine. Mapping Cultures, 237-259.

https://doi.org/10.1057/9781137025050_13

Benjaminsen, T. A., Eira, I. M. G., \& Sara, M. N. (Eds.). (2015). Samisk reindrift, Norske myter. Fagbokforlaget.

Bergland, E. (2005). Reindrift, omstilling og identitet. Guovdageaidnu: Sámi Instituhtta.

Biehl, J., \& Petryna, A. (2013). When People Come First: Critical Studies in Global Health. Princeton: Princeton University Press.

https://doi.org/10.1515/9781400846801

Bjørklund, I. (2004). Saami pastoral society in Northern Norway: the national integration of an indigenous management system. In D. G. Anderson \& M.

Nuttall (Eds.), Cultivating Arctic Landscapes. Knowing and Managing Animals in the Circumpolar North. New York: Berghahn.

Bjørklund, I., \& Marin, A. (2015). Er Finnmarksvidda en allmenning? In T. A. Benjaminsen, I. M. Gaup Eira, \& M. N. Sara (Eds.), Samisk reindrift, Norske myter. Oslo: Fagbokforlaget.

Brown, D. (1970). Bury My Heart at Wounded Knee: An Indian History of the American West. New York: Holt, Rinehart \& Winston.

Cadena, M. d. 1. (2015). Earth Beings. Ecologies of Practices across Andean Worlds. Duke University Press. https://doi.org/10.1215/9780822375265

Cassella, C. (2019). It's Official: There's Nothing We Can Do Now to Stop Arctic Temperature Rise. Retrieved from Dablstron Nilsson, Å. Negotiating Wilderness in a Cultural Landscape: Predators and Saami Reindeer Herding in the Laponian World Heritage Area. (Phd). Uppsala University, Uppsala.

Drugge, A.-L. (Eds.) (2016). Ethics in Indigenous Research: Past Experiences Future. Umeå: Umeå University, Faculty of Arts, Centre for Sami Research. Elenius, L., Allard, C., \& Sandstrøm, C. (Eds.). (2016). Indigenous Rights in Modern Landscapes. Taylor \& Francis Group. https://doi.org/10.4324/9781315607559 
Gulliver, P. (1979). Disputes E negotiations: A cross-cultural Perspective. Academic Press.

Gulliver, P. (1988). Anthropological Contributions to the Study of Negotiations. Negotiation journal, 247-255. https://doi.org/10.1111/j.1571-9979.1988.tb00469.x

Henriksen, J. E. (2008). They can never take my dignety. Social and cultural capital among reindeerherders in Finnmark. In P. Huse (Eds.), Northern Imaginary, 147-151. Delta Press.

Hunt, D., \& Stevenson, S. A. (2016). Decolonizing geographies of power: indigenous digital counter-mapping practices on turtle Island. Settler Colonial Studies, 7:3, 372-392. https://doi.org/10.1080/2201473X.2016.1186311

Hydle, I. (2013). Youth Justice and Restorative Justice in Norway. In K. van Wormer \& L. Walker (Eds.), Restorative Justice Today. Practical Applications (p. 63-74): Sage Publications. https://doi.org/10.4135/9781452244228.n8

Hydle, I., Foss, E. M., \& Lønneberg, M. G. (2014). A study on Norwegian street mediation used in a cross cultural comparison project as part of ALTERNATIVE: Developing alternative understandings of security and justice through restorative justice approaches in intercultural settings within democratic societies. An investigation of the role of gender and age in conflict perception and conflict transformation.

Hydle, I., \& Henriksen, J. E. (2016). Participatory handling of conflicts in Sámi areas. International Social Work. https://doi.org/10.1177/0020872816650731

Ingold, T. (1996). Culture, nature, enviroment. Steps to an ecology of life. Paper. University of Tromsø.

Kaiser, N.,\& Salander Renberg, E. (2012). Suicidal expressions among the Swedish reindeer-herding Sami population, Suicidology Online, 3, 102-113.

Kaiser, N., Sjølander, P., Edin Liljegren, A., \& Jacobsson, L. (2010). Depression and anxiety in the reindeer-herding Sami population of Sweden. International Journal of Circumpolar Health, 69(4), 383-393. https://doi.org/10.3402/ijch.v69i4.17674

Larsen, T., \& Røyrvik, E. A. (Eds.). (2017). Trangen til å telle. Objektivering, måling og standardisering som samfunnspraksis. Oslo: Spartacus Forlag AS. 
Löf, A. (2016). Locking in and locking out: a critical analysis of the governance of reindeer husbandry in Sweden. Critical Policy Studies, 10:4, 426-447. https://doi.org/10.1080/19460171.2015.1098552

Mydske, P. K. M. (Ed.) (2007). Nyliberalisme - Ideer og politisk virkelighet. Oslo: Universitetsforlaget.

Møllersen, S. (2018). Reindriftas hverdag. En undersøkelse av faktorer som kan påvirke psykisk helse til samiske reindriftsutovere i Norge. https:// forskningsprosjekter.ihelse.net/prosjekt/PFP1115-13

Møllersen, S., Eira-Åhren, I. M., Stordahl, V., \& Tørres, G. (2013). Everyday life of reindeer herding. Developing a study to investigate factors that may affect mental health in the Sami. International Journal of Circumpolar Health, 72(1), p. 998-999.

Riseth, J. A., Tømmervik, H., \& Bjerke, J.W. (2016). 175 years of adaptation: North Scandinavian Sámi reindeer herding between government policies and winter climate variability (1835-2010). Journal of Forest Economics, 24, 186204. https://doi.org/10.1016/j.jfe.2016.05.002

Riseth, J. Å., \& Lie, I. (2016). Reindrifta i Finnmarks betydning for næringsutvikling og samfunnsutvikling. In E. Angel, S. Eikeland, \& P. Selle (Eds.), Nordomrädene i endring - Urfolkspolitikk og utvikling (p. 182-207). Oslo: Gyldendahl Akademisk.

Rosaldo, R. (2017). Grief and a Headhunter's Rage In A. C. G. M. Robben (Eds.), Death, Mourning, and Burial: A Cross-Cultural Reader (p. 156-166): WileyBlackwell.

Sara, M. N. (1992). Boazudoallulahki ja boazudoalupolitihkka. Dieđut, 2.

Sara, M. N. (2013). Siida ja siiddastallan. Å vare en siida - om forholdet mellom siidatradisjoner og videreforingen av siidasystemet/Being siida-on the relationship between siida tradition and continuation of the siida system. (Philosophiae Doctor). Sámi Allaskuvla/Sámi University College, Kautokeino.

Sieder, R. (2010). Legal cultures in the (un)rule of law: Indigenous rights and juridification in Guatemala. In J. A. Couso, A. Huneeus, \& R. Sieder (Eds.), Cultures of legality. Judicialization and political activism in Latin America (p. 161-181). Cambridge: Cambridge University Press. https://doi.org/10.1017/CBO9780511730269.007 
Stiglitz, J. (2003). Globalization and Its Discontents. London: Penguin Books Ltd. Stoor, P. (2016). Kunskapssammanställning om samers psykosociala obälsa.

Turner, D. (2006). This is not a Peace Pipe. Towards a critical Indigenous Philosophy. Toronto: University of Toronto Press.

Udtja-Lasse. (2007). Begrav mitt hjärta vid Udtjajaure. Stockholm: Emma publishing.

Woodward, D., \& Lewis, G. M. (1998). Cartography in the Traditional African, American, Arctic, Australian, and Pacific Societies. Humana Press.

Zehr, H. (2014). The Little Book of Restorative Justice. New York: Good Books. 